\title{
STANDARDIZATION OF BEST MANAGEMENT PRACTICES FOR YIELD MAXIMIZATION IN SUNFLOWER (Helianthus annuus L.)
}

\author{
Ullasa, M.Y. ${ }^{{ }^{*}}$, Sheshadri, T. ${ }^{2}$, Geetha, K.N. ${ }^{3}$ and Shankaralingappa, B.C. ${ }^{4}$ \\ ${ }^{1}$ University of Agricultural and Horticultural Sciences, \\ Navile, Shimoga 577225, India \\ ${ }^{2}$ STA, Directorate of Research, University of Agricultural Sciences, \\ GKVK, Bangalore 560065, India \\ 3 All India Coordinated Research Project on Sunflower, \\ GKVK, Bangalore 560065, India \\ ${ }^{4}$ University of Agricultural Sciences, Department of Agronomy, \\ GKVK, Bangalore 560065, India
}

Received: May 28, 2013

Accepted: June 10, 2013

\section{SUMMARY}

A field experiment was conducted to standardize the best management practices for higher yields in sunflower at ZARS, UAS, GKVK, Bengaluru during kharif 2011. The results revealed that application of FYM @ 5 t/ha along with 133 percent RDF (120: 120: $80 \mathrm{~kg} \mathrm{~N}: \mathrm{P}_{2} \mathrm{O}_{5}: \mathrm{K}_{2} \mathrm{O} / \mathrm{ha}$ ) at higher plant population level $\left(\mathrm{P}_{3}-74074\right.$ plants $\left./ \mathrm{ha}\right)$ recorded higher seed yield $(2478 \mathrm{~kg} / \mathrm{ha})$ which was statistically at par with $100 \%$ RDF with same level of FYM and plant population (2464 kg/ha). Higher oil yield was observed with 100\% RDF with FYM @ $5 \mathrm{t} / \mathrm{ha} \&$ higher plant population ( $1014 \mathrm{~kg} / \mathrm{ha}$ ) followed by $133 \% \mathrm{RDF}(1011 \mathrm{~kg} /$ ha). Hence, adoption of higher plant population level of 74074 plants/ha along with 100 percent RDF and FYM (5 t/ha) is sufficient to generate remunerative income (Rs. 51450/ha) and higher B:C ratio (3.29).

Key words: sunflower, farmyard manure, fertilizers and plant population, yield maximization

\section{INTRODUCTION}

Sunflower is one of the important oilseed crops and its oil is generally considered as premium oil and fetches higher value in the market because of its light colour and high level of poly unsaturated fatty acids (PUFA). Since, in India it is cultivated in an area of $0.9 \mathrm{~m} . \mathrm{ha}$, with total annual production of $0.63 \mathrm{~m}$. tonnes and productivity of $696 \mathrm{~kg}$ per ha (Anonymous, 2012). The crop has the potential to yield at least $1,000 \mathrm{~kg} / \mathrm{ha}$ under rain fed condition, with proper care. Under assured rainfall situations, the yield can be increased up to $2000 \mathrm{~kg} / \mathrm{ha}$. The major con-

* Corresponding author: e-mail: ullas.653@gmail.com 
straints are inadequate and imbalanced crop nutrition and poor maintenance of optimum plant population.

Keeping these points in view a field experiment entitled "Standardization of best management practices for yield maximization in sunflower" was conducted at Zonal Agricultural Research Station, Gandhi Krishi Vignana Kendra, University of Agricultural Sciences, Bengaluru, during kharif 2011.

\section{MATERIALS AND METHODS}

Soil texture of the experimental site red sandy loam with $201 \mathrm{~kg}$ available nitrogen/ha, $19 \mathrm{~kg}$ available phosphorus/ha and $175 \mathrm{~kg}$ available potassium/ha. Available sulphur, zinc and boron status of the soil was 14, 0.84 and $0.25 \mathrm{ppm}$, respectively.

A Field Experiment Conducted at ZARS GKVK Bengaluru in a split plot design with three replications. Two levels of FYM (control \& $5 \mathrm{t} / \mathrm{ha}$ ) in main plot and factorial combination of three plant populations $\left(\mathrm{P}_{1}-55555\right.$ plants/ha, $\mathrm{P}_{2}-37037$ plants/ ha and $\mathrm{P}_{3}-74074$ plants/ha) with three fertilizer levels $\left(\mathrm{F}_{1}-100 \% \mathrm{RDF}, \mathrm{F}_{2}-125 \% \mathrm{RDF}\right.$, $\mathrm{F}_{3}-133 \% \mathrm{RDF}$ ) were assigned to subplots. Limiting nutrients ( $\mathrm{S}, \mathrm{Zn}, \mathrm{B}$ ) were applied as blanket recommendation based on soil test values. Half the dose of nitrogen and full dose of phosphorus and potassium and limiting nutrients were applied as basal dose as per treatments. Remaining 50 percent nitrogen was top dressed at 30 days after sowing. The crop was sown on July $17^{\text {th }} 2011$. The crop received good rainfall throughout the crop duration. Normal weather conditions are prevailed during the crop growth.

Observation on dry matter, head diameter, test weight, seed yield, oil yield were recorded at the time of harvesting and the data is subjected for $\mathrm{F}$ test $5 \%$ level of significance as per the procedure outlaid by Gomez and Gomez (1984) and 't' test as worked whenever ' $\mathrm{F}$ " test found significant. The economics were worked considering the prevailing market price.

\section{RESULTS AND DISCUSSION}

\section{Effect of application of FYM}

The data (Table 1) revealed that application of FYM did not influence the seed yield significantly. Higher seed yield $(2215 \mathrm{~kg} / \mathrm{ha})$ was recorded with the application of FYM (5 t/ha) compared to control (2095 kg/ha).

The higher seed yield due to application FYM (5 t/ha) might be attributed to higher leaf area index $(0.87,4.29,2.8)$ as compared to control $(0.75,4.28,2.7)$ at 30,60 and 90 DAS, respectively.

The, yield difference between FYM application and control could be attributed to numerical variation in other yield components such as higher leaf area, test 
weight and yield per plant. All these components recorded higher values (5.86 g, 62 $\mathrm{g}$, respectively) with application of FYM (5 t/ha) as compared to control (5.83 g, $61 \mathrm{~g}$ respectively). Similar trends were also observed with respect to oil yield. These results are in conformity with Jayaramaiah et al. (2005).

Table 1: Effect of FYM, plant population levels and different fertilizer levels on growth and yield of sunflower

\begin{tabular}{|c|c|c|c|c|c|c|c|c|c|}
\hline \multirow{3}{*}{ Treatments } & \multicolumn{3}{|c|}{ Leaf Area Index } & \multirow{2}{*}{$\begin{array}{c}\text { Dry } \\
\text { Matter }\end{array}$} & \multirow{3}{*}{$\begin{array}{c}\begin{array}{c}\text { Head } \\
\text { diameter }\end{array} \\
(\mathrm{cm})\end{array}$} & \multirow{2}{*}{$\begin{array}{c}\text { Test } \\
\text { weight }\end{array}$} & \multirow{2}{*}{$\begin{array}{l}\text { Seed } \\
\text { Yield }\end{array}$} & \multirow{2}{*}{$\begin{array}{l}\text { Seed } \\
\text { yield }\end{array}$} & \multirow{2}{*}{$\begin{array}{c}\text { Oil } \\
\text { yield }\end{array}$} \\
\hline & 30 & 60 & 90 & & & & & & \\
\hline & DAS & DAS & DAS & (g/plant) & & (g/100 seeds) & (g/plant) & (kg/ha) & (kg/ha) \\
\hline \multicolumn{10}{|c|}{ Farmyard manure (FYM) } \\
\hline$M_{1}$-No FYM (Control) & 0.75 & 4.28 & 2.6 & 149 & 17.5 & 5.83 & 61 & 2095 & 844 \\
\hline$M_{2}-F Y M(5 t / h a)$ & 0.87 & 4.29 & 2.5 & 150 & 16.4 & 5.86 & 62 & 2215 & 900 \\
\hline S.Em. \pm & 0.01 & 0.13 & 0.08 & 1.54 & 0.26 & 0.07 & 1.6 & 100 & 38.8 \\
\hline $\mathrm{LSD}_{0.05}$ & 0.06 & NS & NS & NS & NS & NS & NS & NS & NS \\
\hline \multicolumn{10}{|c|}{ Plant population (plants/ha) } \\
\hline$P_{1}-55555(60 \times 30 \mathrm{~cm})$ & 0.90 & 4.66 & 2.4 & 146 & 16.5 & 5.72 & 57 & 2140 & 867 \\
\hline$P_{2}-37037(60 \times 45 \mathrm{~cm})$ & 0.50 & 3.13 & 2.4 & 173 & 18.2 & 6.27 & 73 & 2036 & 821 \\
\hline $\mathrm{P}_{3}-74074(60 \times 22.5 \mathrm{~cm})$ & 1.03 & 5.08 & 2.8 & 129 & 16.2 & 5.54 & 56 & 2289 & 928 \\
\hline S.Em. \pm & 0.036 & 0.17 & 0.07 & 1.94 & 0.35 & 0.11 & 3.5 & 50 & 22.0 \\
\hline $\operatorname{LSD}_{0.05}$ & 0.10 & 0.50 & 0.21 & 5.6 & 0.99 & 0.31 & 10 & 146 & 64 \\
\hline \multicolumn{10}{|c|}{ Fertilizer level (RDF= 90:90:60 NPK kg/ha) } \\
\hline$F_{1}-100 \%$ RDF & 0.83 & 4.02 & 2.3 & 141 & 16.5 & 5.67 & 61 & 2146 & 875 \\
\hline$F_{2^{-}} 125 \%$ RDF & 0.86 & 4.31 & 2.8 & 142 & 17.1 & 5.91 & 60 & 2134 & 861 \\
\hline$F_{3}-133 \%$ RDF & 0.73 & 4.53 & 2.5 & 165 & 17.3 & 5.95 & 64 & 2185 & 880 \\
\hline S.Em. \pm & 0.036 & 0.17 & 0.07 & 1.94 & 0.35 & 0.11 & 3.5 & 50 & 22.0 \\
\hline LSD $_{0.05}$ & 0.10 & NS & 0.21 & 5.6 & NS & NS & NS & NS & NS \\
\hline
\end{tabular}

Note:

-Farm yard manure $(M), M_{1}$ - No FYM, $M_{2}-F Y M$ 5t/ha, Plant Population (P) - $P_{1}-55555$ plants/ha, $P_{2^{-}}$ 37037 plants/ha, $P_{3}-74074$ plants/ha, Fertilizer levels $(F)-F_{1}-100 \%$ RDF, $F_{2}-125 \%$ RDF, $F_{3}-133 \%$ RDF.

\section{Effect of plant population}

The higher plant population (74074 plants/ha) recorded significantly higher seed yield (2289 kg/ha) compared to both recommended plant population of 55555 plants/ha $(2140 \mathrm{~kg} / \mathrm{ha})$ and reduced plant population of 37037 plants/ha (2036 kg/ ha). This is in conformity with the findings of Patel and Thakur (2003).

Leaf area is most important indices in photosynthesis, in plant population experiments, which is meaningfully interpreted in terms of LAI. Significantly higher LAI ( $1.03,5.08,2.80$ at 30, 60 and 90 days after sowing, respectively) was recorded in higher plant population 74074 plants/ha, as compared to lower plant population 37037 plants/ha $(0.5,3.13,2.4$ at 30, 60 and 90 days after sowing, respectively).

Though significantly higher head diameter $(18.2 \mathrm{~cm})$ and test weight $(6.27 \mathrm{~g})$ and per plant productivity (73 g) was recorded with reduced (37037 plants/ha) 
plant population, it could not compensate the yield that was achieved under high plant population 74074 plants/ha (2289 kg/ha).

By increasing plant population level from 55555 to 74074 has not resulted in any reduction in per plant productivity. The per plant productivity of 55555 and 74074 plants/ha were almost similar (57 and 56 g, respectively). Higher per plant productivity coupled with higher plant population might be the main reason behind higher productivity in 74074 plants/ha. The similar per plant yield with 55555 and 74074 plants/ha is attributed to non significant difference in yield parameters such as head diameter $(16.5$ and $16.2 \mathrm{~cm})$ and test weight $(5.72$ and 5.54$)$ between 55555 and 74074 plants/ha, respectively. Under lower plant population levels resources might not have been used effectively due to lower leaf area index. These results are in conformity with those obtained by Intodia and Tomar (1997) and Satish Kumar et al. (2011).

\section{Effect of fertilizer levels}

Although seed yield differences due to graded levels of fertilizers were non significant, the higher seed yield (2185 kg/ha) was recorded with application of $133 \%$ RDF (120:120:80 kg N: $\mathrm{P}_{2} \mathrm{O}_{5}: \mathrm{K}_{2} \mathrm{O} / \mathrm{ha}$ ). This is in conformity with findings of Chaudhari et al. (1978).

Yield components such as head diameter $(17.3 \mathrm{~cm})$, test weight $(5.95 \mathrm{~g})$ and seed yield/plant ( $64 \mathrm{~g}$ ) were higher with application of $133 \% \mathrm{RDF}$, which might have contributed for higher grain yield. This is in conformity with the findings of Chitale et al. (2004).

The seed yield and yield components are indirectly influenced by different growth parameters like dry matter production and leaf area index. Application of $133 \%$ RDF has recorded higher dry matter production ( $165 \mathrm{~g} /$ plant) as compared to application of $100 \% \mathrm{RDF}$ (141 g/plant) at harvest which might have resulted in increased yield with application of $133 \% \mathrm{RDF}$.

Leaf area index also recorded higher values (4.53 and 2.50) with application of $133 \% \mathrm{RDF}$ as compared to $100 \% \mathrm{RDF}$ ( 4.02 and 2.30 ) at 60 and 90 days after sowing, respectively. This lower LAI might have caused the crop for producing lower total dry matter with $100 \% \mathrm{RDF}$ and it was reflected in terms of yield parameters also.

\section{Interaction effect}

The results (Table 2) revealed that application of $5 \mathrm{t}$ FYM along with 133 percent RDF at higher plant population level 74074 plants/ha recorded higher seed yield ( $2478 \mathrm{~kg} / \mathrm{ha}$ ). With same level of plant population and FYM, by decreasing the fertilizer level from $133 \%$ to $100 \%$ of RDF has at par in seed yield $(2464 \mathrm{~kg} / \mathrm{ha})$. Oil yield at $100 \% \mathrm{RDF}$ along with $5 \mathrm{t} \mathrm{FYM/ha}$ at plant population level of 74074 plants/ ha (1014 kg/ha) was higher as compared to application of $133 \%$ RDF at same level of plant population and FYM. Hence, application of 100 percent RDF and 5 t FYM 
along with plant population of 74074 plants/ha is sufficient to get higher oil yield (1014 kg/ha).

\section{Economics}

Higher B:C ratio (3.29) and net returns (Rs. 51450/ha) were realised due to application of FYM ( $5 \mathrm{t} / \mathrm{ha}$ ) and 100\% RDF at plant population level of 74074 plants /ha (Table 2). Higher net returns and B:C ratio was achieved due to lower cost of cultivation (Rs. 22481/ha) and higher gross returns (Rs. 73931/ha).

Table 2: Seed yield, oil yield and economics of sunflower as influenced by application of FYM, plant population levels of fertilizer levels

\begin{tabular}{|c|c|c|c|c|c|c|}
\hline \multirow[t]{2}{*}{ Treatments } & Seed yield & Oil yield & $\begin{array}{l}\text { Cost of } \\
\text { cultivation }\end{array}$ & $\begin{array}{l}\text { Gross * } \\
\text { return }\end{array}$ & Net return & $\mathrm{B}: \mathrm{C}$ ratio \\
\hline & (kg/ha) & (kg/ha) & (Rs./ha) & (Rs./ha) & (Rs./ha) & \\
\hline $\mathrm{M}_{1} \mathrm{P}_{1} \mathrm{~F}_{1}$ & 2063 & 840 & 19471 & 61898 & 42427 & 3.18 \\
\hline$M_{1} P_{1} F_{2}$ & 2074 & 833 & 20327 & 62241 & 41914 & 3.06 \\
\hline$M_{1} P_{1} F_{3}$ & 2131 & 865 & 20601 & 63950 & 43349 & 3.10 \\
\hline $\mathrm{M}_{1} \mathrm{P}_{2} \mathrm{~F}_{1}$ & 2129 & 872 & 19056 & 63888 & 44832 & 3.25 \\
\hline $\mathrm{M}_{1} \mathrm{P}_{2} \mathrm{~F}_{2}$ & 1852 & 738 & 19912 & 55586 & 35674 & 2.79 \\
\hline $\mathrm{M}_{1} \mathrm{P}_{2} \mathrm{~F}_{3}$ & 2177 & 864 & 20186 & 65316 & 45130 & 3.23 \\
\hline$M_{1} P_{3} F_{1}$ & 1950 & 778 & 19981 & 58507 & 38526 & 2.92 \\
\hline $\mathrm{M}_{1} \mathrm{P}_{3} \mathrm{~F}_{2}$ & 2227 & 904 & 20831 & 66813 & 45976 & 3.20 \\
\hline $\mathrm{M}_{1} \mathrm{P}_{3} \mathrm{~F}_{3}$ & 2251 & 899 & 21111 & 67546 & 46435 & 3.20 \\
\hline $\mathrm{M}_{2} \mathrm{P}_{1} \mathrm{~F}_{1}$ & 2057 & 848 & 21971 & 61709 & 39738 & 2.81 \\
\hline $\mathrm{M}_{2} \mathrm{P}_{1} \mathrm{~F}_{2}$ & 2321 & 931 & 22827 & 69645 & 46818 & 3.05 \\
\hline $\mathrm{M}_{2} \mathrm{P}_{1} \mathrm{~F}_{3}$ & 2190 & 885 & 23101 & 65717 & 42616 & 2.84 \\
\hline $\mathrm{M}_{2} \mathrm{P}_{2} \mathrm{~F}_{1}$ & 2212 & 894 & 21556 & 66373 & 44817 & 3.07 \\
\hline $\mathrm{M}_{2} \mathrm{P}_{2} \mathrm{~F}_{2}$ & 1965 & 798 & 22412 & 58958 & 36546 & 2.63 \\
\hline $\mathrm{M}_{2} \mathrm{P}_{2} \mathrm{~F}_{3}$ & 1879 & 756 & 22686 & 56381 & 33695 & 2.48 \\
\hline $\mathrm{M}_{2} \mathrm{P}_{3} \mathrm{~F}_{1}$ & 2464 & 1014 & 22481 & 73931 & 51450 & 3.29 \\
\hline $\mathrm{M}_{2} \mathrm{P}_{3} \mathrm{~F}_{2}$ & 2364 & 960 & 23337 & 70933 & 47596 & 3.04 \\
\hline $\mathrm{M}_{2} \mathrm{P}_{3} \mathrm{~F}_{3}$ & 2478 & 1011 & 23611 & 74336 & 50725 & 3.14 \\
\hline S.Em \pm & 124 & 54.6 & 3721 & 3721 & 2631 & 0.17 \\
\hline $\mathrm{LSD}_{0.05}$ & NS & NS & NS & NS & NS & NS \\
\hline
\end{tabular}

* Market price of sunflower seed Rs. 3000/q.

Note:

-Farm yard manure (M), $M_{1}$ - No FYM, $M_{2}-F Y M$ 5t/ha, Plant Population (P) - $P_{1}-55555$ plants/ha, $P_{2^{-}}$ 37037 plants/ha, $P_{3}-74074$ plants/ha, Fertilizer levels $(F)-F_{1}-100 \%$ RDF, $F_{2}-125 \% R D F, F_{3}-133 \% R D F$.

Thus it can be concluded that application of 100 per cent RDF and FYM ( 5 t/ha) with 74074 plants/ha is sufficient to get higher economic yields in sunflower. 


\section{ACKNOWLEDGEMENTS}

All type of help rendered by the All India Coordinated Research Project on sunflower Bangalore during course of study to the author is gratefully acknowledged.

\section{NOTES}

Ullasa, M.Y. ${ }^{1}$, Sheshadri, T. ${ }^{2}$, Geetha, K.N. ${ }^{3}$ and Shankaralingappa, B.C. ${ }^{4}$

1. Senior Research Fellow precision Farming project, University of Agricultural and Horticultural Sciences, Navile, Shimoga 577225 India. (ullas.653@gmail.com)

2. STA, Directorate of research University of Agricultural Sciences, GKVK, Bangalore 560065, India. (toresalu@rediffmail.com)

3. Agronomist, All India Coordinated Research Project on Sunflower, GKVK, Bangalore 560065, India. (geethagowda@hotmail.com)

4. Professor and Head department of Agronomy, University of Agricultural Sciences, GKVK, Bangalore -560065, India.

\section{REFERENCES}

Anonymous, 2012. Annual Group Meeting on Sunflower, Project Director's Report, Directorate Of Oilseed Research, Rajendranagar, Hyderabad, pp. 16.

Chaudhari, C.S., Mahajan, A.G. and Paturde, J.T., 1978. Effect of plant populations and fertility levels on sunflower. Indian J. Agron. 23: 153-156.

Chitale, S.S.K., Upadhyay, R.K., Bajpai, R.K. and Joshi, B.S., 2004. Effect of higher fertility levels combined with farmyard manure and row spacing on seed yield, oil yield and economics of sunflower, Helianthus annuus L. J. Oilseeds Res. 21: 189-191.

Gomez, K.A. and Gomez, A.A., 1984. Statistical procedure for agric. res. $2^{\text {nd }}$ Ed. John Wiley \& Sons, New York.

Intodia, S.K. and Tomar, O.P., 1997. Effect of sulphur application on growth and yield of sunflower (Helianthus annuus L.). Indian J. Agric. Sci. 67: 46-47.

Jayaramaiah, R., Thimmegowda, S., Chalapathi, M.V., Devakumar, N., Rangaswamy, B.T., Basavarajappa, H.R. and Rudramuni, T., 2005. Impact of residual organic manure, irrigation and fertilizer levels on growth and yield of sunflower. Karnataka J. Agric. Sci. 18: 494-496.

Patel, S.R. and Thakur, D.S., 2003. Effect of crop geometry, phosphorus levels and phosphate solubilizing bacteria on growth, yield and oil content of sunflower, Helianthus annuus L. J. Oilseeds Res. 20: 153-154.

Satish Kumar, Tewari, S.K. and Singh, S.S., 2011. Effect of source and levels of sulphur and spacing on the growth, yield and quality of spring sunflower (Helianthus annuus L). Indian J. Agron. 56: 242-246. 